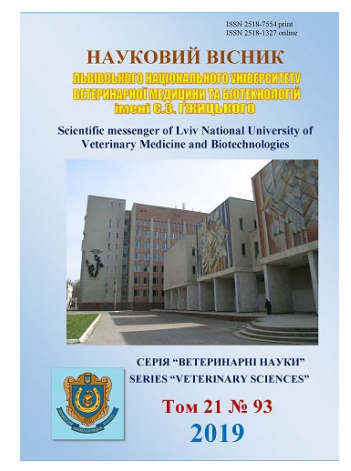

\author{
Науковий вісник Дьвівського національного університету \\ ветеринарної медицини та біотехнологій імені С.З. Гжицького. \\ Серія: Ветеринарні науки \\ Scientific Messenger of Lviv National University \\ of Veterinary Medicine and Biotechnologies. \\ Series: Veterinary sciences
}

\title{
Changes in cellular factors of local immunity udder of cows with mastitis
}

\author{
M.M. Zhelavskyi ${ }^{1}$, O.Ya. Dmytriv², V.P. Mizyk ${ }^{1}$ \\ ${ }^{1}$ Podilya State Agrarian and Engineering University, Kamyanets-Podilsky, Ukraine \\ ${ }^{2}$ Stepan Gzhytskyi National University of Veterinary Medicine and Biotechnologies Lviv, Ukraine
}

Article info

Received 21.01.2019

Received in revised form 04.03 .2019

Accepted 05.03.2019

Podilya State Agrarian and Engineering University,

Shevchenko Str., 13,

Kamyanets-Podilsky, 32300,

Khmelnytskyi Region, Ukraine. Tel.: +38-097-905-34-23

E-mail:nicoladoctor@gmail.com

Stepan Gzhytskyi National University of Veterinary Medicine and Biotechnologies Lviv,

Pekarska Str., 50, Lviv,

79010, Ukraine.

\begin{abstract}
Zhelavskyi, M.M., Dmytriv, O.Ya., \& Mizyk, V.P. (2019). Changes in cellular factors of local immunity udder of cows with mastitis. Scientific Messenger of Lviv National University of Veterinary Medicine and Biotechnologies. Series: Veterinary sciences, 21(93), 46-52. doi: 10.32718/nvlvet9309

The immunological aspects of lactation of cows are investigated in this work. The authors present modern scientific data on the local immune protection of the mammary gland of cows. The purpose of the research was to improve the laboratory methods of diagnosis of mastitis and to study the cytological composition of the secretion of the breast of the cows for subclinical and purulent catarrhal inflammation of the udder. The cytological differentiation of milk cells was carried out according to its own developed, tested and patented method. Our experimental data convincingly confirm that in subclinical and purulentcatarrhal mastitis in cows there are significant changes in changes in the cytological composition and the system of local immune defense of the mammary gland. An important role in inflammation of the mammary gland is played by neutrophilic granulocytes that migrate to the parenchyma at the beginning of the clinical pathology (with subclinical inflammation) and release a range of inflammatory mediators in the inflammation zone. Subclinical mastitis of cows is accompanied by a sharp increase in the total somatic cells count in the secretion of the mammary gland. This is due to the activity of neutrophilic granulocytes, monocytes of histiocytes. Corresponding changes were found in the cytological balance of immunocompetent cells of the secretion of cows at from subclinical mastitis. The most significant shift was noted in the index of migratory activity of neutrophils $(P<0.01)$, which is a specific "indicator" indicator of inflammatory response in the body of diseased animals. Subclinical inflammation was also manifested by a decrease in the migration activity of lymphocytes. At purulent-catarrhal mastitis of cows there is a significant increase in the number of somatic cells. Also, the migration activity of neutrophils and histiocytes in the pathologic process zone is increasing and changes in the balance of immune cells are established. Thus, our experimental data convincingly confirm that in subclinical and purulent-catarrhal mastitis in cows there are significant changes in the system of local immune defense of the mammary gland. It has an important diagnostic value and also needs immunocorrection in the treatment process.
\end{abstract}

Key words: cows, mammary gland, lactation, mastitis, diagnostic, phagocytes, innate immunity, immune homeostasis.

\section{Introduction}

From the middle of the last century, researchers from different countries conducted an active search for informative methods for diagnosing sub clinical mastitis of cows (Hamilton et al., 2006; Green et al., 2007). Most developments were based on determining the number of somatic cells in the secretion of the mammary gland (Call et al., 2008; Blum et al., 2015; Abebe et al., 2016; Kempf et al., 2016). While most of the techniques are based on determining the number of somatic cells as a diagnostic criterion for the diagnosis of subclinical pathology of cows (Yablonskyi and Zhelavskyi, 2007; Kurjogi et al., 2014; Thompson-Crispi et al., 2014; Wu et al., 2015; Delfani et al., 2017; Cao et al., 2018). Despite this, the researchers constantly encountered problems in interpreting the results (Singh et al., 2011; Wang et al., 2014; AlFarha et al., 2017; Sato et al., 2017). It was related to the of dynamic changes in the quantitative composition of somatic cells in different periods of lactation, daily oscillations in their numbers; study species and individual peculiarities of animals (Zhelavskyi, 2005; Kurjogi et al., 2014; Lombardini et al., 2017; Pang et al., 2017). 
Significant difficulties were the definition of subclinical mastitis in the early period of lactation. The study of colostrum and secretion of the mammary gland in the final period of lactation (Zhelavskyi, 2007; Yablonskyi and Zhelavskyi, 2009; Ndhlovu et al., 2017).

The prospect in this area is the development of new informative methods for diagnosing sublinear mastitis of cows based on the identification of the functional state of phagocyte cells (Zhelavskyi, 2015; 2017). For now, most developed express methods are based only on determining the number of cells (Hamilton et al., 2006; Green et al., 2007; Singh et al., 2011; Thompson-Crispi et al., 2014; Delfani et al., 2017).

The purpose of the research was to improve the laboratory methods of diagnosis of mastitis and to study the cytological composition of the secretion of the breast of the cows for subclinical and purulent catarrhal inflammation of the udder.

\section{Material and methods}

Clinical and experimental studies were conducted in Ukrainian farms (Khmelnytsky and Vinnytsia region). Laboratory studies were carried out in the specialized laboratory of immunology of animal reproduction of the Faculty of Veterinary Medicine of the Podilsky State Agrarian and Technical University (Kamyanets-Podilsky, Khmelnytsky Region, Ukraine).

The experiments were conducted on cows-analogues of the Ukrainian black-and-white dairy breed using the method of groups and periods. To conduct clinical and experimental studies, three groups of animals were formed.

Group 1 - control (Control, $\mathrm{n}=32$ ) - clinically healthy cows.

Group 2 - research $(\mathrm{R} 1, \mathrm{n}=58)$ consisted of animals with subclinical mastitis.

Group $3-(\mathrm{R} 3, \mathrm{n}=28)$ consisted of cows with a clinical diagnosis: purulent-catarrhal mastitis.

A complex study of the immunobiological status was carried out during the testing of non-specific immunobiological resistance. The cytological differentiation of the cells of milk was carried out according to its patented method (Patent 58403 Ukraine).

Samples of alveolar milk were taken for cytological examination of the secretion of the mammary gland, adhering to the necessary rules of asepsis and antiseptics. An informative diagnostic method has been developed that allows for accurate cytological diagnostic. The essence of the method is that the secretion of the cells of the mammary gland was carried out by sedimentation in the gradient of density of the Ficoll - Verofragine. Innovation and perfection of the technique is the ability to isolate a pure cell suspension of immune cells. And also in the possibility of conducting a clear differential assessment and in the future to conduct a series of cytochemical and immunological studies.

Method for secretion of the cell cervical mammary secretion.
A sample of milk $(1.0 \mathrm{ml})$ was placed on a gradient of density Ficoll 400 (type 400-DL, Sigma Aldrich) \& Verografin $\left(\rho 1.077 \mathrm{~g} / \mathrm{cm}^{3}\right)$ and centrifuged for 20 minutes at $1500 \mathrm{rpm}$. After this, an interphase medium containing a cell pool was taken. Next $0.15 \mathrm{ml}$ of a cell suspension were taken, which was applied to the skimmed glass and prepared a smear. The preparation was dried in air (5-7 minutes) at room temperature $\left(\mathrm{t} \sim 18-22^{\circ} \mathrm{C}\right)$ and fixed (3-5 min) Methanol $\left(90^{\circ}\right)$. Finished microslide stain on the method of Romanovsky-Giemsa and Papeenheim.

Microscopy of the microsphere is made by an increase of 2500. Further, a pure cell pool was isolated and cytological differentiation of somatic cells count (SCC, cells/ml x1000) was determined, with their varieties (lymphocytes, neutrophils, monocytes, histiocytes, epithelial cells, separate nuclei, non-nuclear cell structures).

When biometric processing of data arrays, other immunological parameters were also indicated: the index of migration activity of lymphocytes (IMAL), the index of migration activity of neutrophils (IMAN), the index of transformation of macrophage transformation (IMT), the lymphocyte-granulocytic index (LGI) (Yablonskyi and Zhelavskyi, 2001; 2009; 2014).

This study was approved according to the Law of Ukraine "On the Protection of Animals from Cruel Treatment" (No. 3447-IV of February 21, 2006) and all animal manipulations were carried out in accordance with the European Convention for the Protection of Vertebrate Animals used for experimental and scientific purposes (Strasbourg, 18 March 1986). All experiments were carried out with the Ethical Permit at the State Agrarian and Engineering University in Podilya. Mathematical processing of research results was processed statistically using the Statistica 6.0 software package. The results of the mean values were considered statistically significant at $*_{-} \mathrm{P}<0.05,{ }^{*}-\mathrm{P}<0.001$ (ANOVA).

\section{Results and discussion}

Lactation is a high-energy process accompanied by significant metabolic and neurohumoral regulation. During lactation, the tension is also manifested by physiological fluctuations in the parameters of immune homeostasis. Changes occur at both the local and systemic levels of immune defense, the development of which leads to the emergence and development of mastitis.

Studies have shown that subclinical mastitis of cows is marked by a sharp increase of the total somatic cells count of secret, which almost ten times (3819.23 \pm $76.36 \mathrm{cell} / \mathrm{ml} \times 1000, \mathrm{P}<0.01)$ exceeded the control index. The inflammatory reaction in udder (and in the body as a whole) was accompanied by significant changes in the cytological composition of the secretion. At the forefront was a sharp increase in the secretion of the mammary gland in the population of primed (in active standby) neutrophil granulocytes $(50.73 \pm 1.34 \%, \mathrm{P}<0.01)$. This which testified to the primary involvement of phagocytes in the complex mechanism of the pathogenesis of the disease (table 1). 
Table 1

Changes in the cytological composition of the secretion of the mammary glands of the cows under the subclinical mastitis $(\mathrm{M} \pm \mathrm{m})$

\begin{tabular}{|c|c|c|c|c|c|c|c|c|c|}
\hline \multirow{3}{*}{ Variable } & \multicolumn{9}{|c|}{ Investigated cytological parameters: } \\
\hline & \multirow[b]{2}{*}{$\begin{array}{c}\text { SCC, cells } / \mathrm{ml} \\
\times 1000\end{array}$} & \multicolumn{4}{|c|}{ Leukocytes: } & \multirow[b]{2}{*}{$\begin{array}{l}\text { Hystiocyte } \\
\text { s, } \%\end{array}$} & \multirow[b]{2}{*}{$\begin{array}{l}\text { Epithelial } \\
\text { cells, } \%\end{array}$} & \multirow{2}{*}{$\begin{array}{l}\text { Separate } \\
\text { nuclei, } \%\end{array}$} & \multirow{2}{*}{$\begin{array}{c}\text { Non-nuclear } \\
\text { cell } \\
\text { structures, } \%\end{array}$} \\
\hline & & $\begin{array}{c}\text { Neutrophils, } \\
\%\end{array}$ & $\begin{array}{c}\text { Lymphocytes, } \\
\%\end{array}$ & $\begin{array}{c}\text { Monocytes, } \\
\%\end{array}$ & $\begin{array}{l}\text { The total } \\
\text { number }\end{array}$ & & & & \\
\hline $\begin{array}{l}\text { Clinically } \\
\text { healthy ( } \mathrm{n} \\
=33)\end{array}$ & $\begin{array}{r}255.72 \pm \\
17.5\end{array}$ & $\begin{array}{r}44.69 \pm \\
0,58\end{array}$ & $\begin{array}{r}3.87 \pm \\
0.33\end{array}$ & $\begin{array}{r}1.93 \pm \\
0.24\end{array}$ & $\begin{array}{r}50.51 \pm \\
1.05\end{array}$ & $\begin{array}{r}4.18 \pm \\
0.39\end{array}$ & $\begin{array}{r}42.60 \pm \\
0.89\end{array}$ & $\begin{array}{r}1.75 \pm \\
0.07\end{array}$ & $\begin{array}{r}1.15 \pm \\
0.36\end{array}$ \\
\hline $\begin{array}{l}\text { Subclinical } \\
\text { mastitis } \\
(n=37)\end{array}$ & $\begin{array}{c}3819.23 \pm \\
76.36^{* *}\end{array}$ & $\begin{array}{c}50.73 \pm \\
1.34^{* *}\end{array}$ & $\begin{array}{c}2.33 \pm \\
0.43^{*}\end{array}$ & $\begin{array}{l}4.28 \pm \\
0.51^{* *}\end{array}$ & $\begin{array}{l}57.26 \pm \\
1.22^{* *}\end{array}$ & $\begin{array}{r}8.2 \pm \\
0.51^{* *}\end{array}$ & $\begin{array}{c}32.55 \pm \\
1.38^{* *}\end{array}$ & $\begin{array}{l}0.78 \pm \\
0.04^{* *}\end{array}$ & $\begin{array}{r}1.18 \pm \\
0.39\end{array}$ \\
\hline
\end{tabular}

Notes: the degree of reliability compared with data of the control group: ${ }^{*}-\mathrm{P}<0.05 ;^{* *}-\mathrm{P}<0.01$.

In microslides, the population of monocytes $(4.28 \pm$ $0.51 \%, \mathrm{P}<0.01)$ and other microphage cells - histiocytes, whose number almost doubled $(8.2 \pm 0.41 \%)$ - exceeded their level in clinically healthy cows $(4.18 \pm 0.39 \%)$. The pathological process was also accompanied by a relative decrease in the secretion of the number of epithelial cells (by almost $10 \%, \mathrm{P}<0.01$ ) and a two-fold decrease in seperate nuclei $(0.78 \pm 0.04 \%, \mathrm{P}<0.01)$, indicating a secretory dysfunctions of the mammary gland.

Corresponding changes were found in the cytological balance of immunocompetent cells of the secretion of cows at from subclinical mastitis. The most significant shift was noted in the index of migratory activity of neutrophils $(1.44 \pm 0.17$ vs. $0.86 \pm 0.07, \mathrm{P}<0.01)$, which is a specific "indicator" indicator of inflammatory response in the body of diseased animals. Subclinical inflammation was also manifested by a decrease in the migration activity of lymphocytes (IMAL $-0.04 \pm 0.01$ versus $0.07 \pm$ $0.02, \mathrm{P}<0.01$ ) and decreased transformation ability of macrophages (ITM $-1.91 \pm 0.01$ versus $2.16 \pm 0.02$ ). This, in turn, indicated an initial dysfunction in the macrophage-level immune system.

Changes in the population balance of immunocompetent cells have also been reflected in the lymphocytic granulocyte index. This which in turn confirms that the acute phase of the inflammatory process manifests itself as a violent activation of neutrophils - primary inflammatory messengers. Certain features of local immunity are noted in the development of purulent-catarrhal mastitis of cows. Clinical research methods showed a general oppression in patients with cows, a sharp increase in body temperature to $40-41{ }^{\circ} \mathrm{C}$, tachycardia (93-107 beats per minute), tachypnoea (32-47 breaths per minute), decrease in lactation.
The inflamed part of the mammary gland increased in size, acquired a condensed consistency, the skin was tense and hyperemia. Palpation has shown a strong pain reaction. In all cases, we have diagnosed an increase in the surface lymph node from the affected part of the organ. The secret of the gland was acquired in a grayish-white or yellowish color, creamy or creamy consistency containing admixture of cereals and manure and had a specific odor.

Analyzing the data it can be noted that purulentcatarrhal mastitis is accompanied by significant changes in the cytological composition of the milk secretion of sick cows. Acute inflammatory reaction revealed a significant increase in the total somatic cells count in milk $(8448.52 \pm 180.98$ versus $255.72 \pm 17.5 \mathrm{cell} / \mathrm{ml} \times 1000$ in clinically healthy cows, $\mathrm{P}<0.01)$. Purulent-catarrhal exudation of the mammary gland was also accompanied by an increase in its share of neutrophil granulocytes (by almost $14 \%$ ) and a slight increase in the percentage of histiocytic cells $(4.41 \pm 0.88$ versus $4.18 \pm 0.39 \%)$.

Purulent-catarrhal mastitis of cows also manifests itself a change in the cytological balance of immunocompetent cells of the secretion of the mammary gland. First of all, it should be noted that the inflammatory reaction was manifested here by a sharp increase in the index of IMAN $(1.55 \pm 0.02$ vs. $0.86 \pm 0.07, \mathrm{P}<0.01)$. This fact clearly confirmed that the purulent-catarrhal inflammatory reaction occurred in the background of the activation of the migration capacity of neutrophils into the pathological process. Obviously, neutrophilic granulocytes, which migrated to the parenchyma of the udder, even at the onset of clinical pathology (with subclinical inflammation). In this case, a number of hematrons, cytokines, enzymes, etc. in the inflammation zone extrude, which is important in the pathogenesis of purulent-catarrhal inflammation.

Table 2

Cytological balance of immunocompetent cervical secretion secretion cells in subclinical mastitis $(\mathrm{M} \pm \mathrm{m})$

\begin{tabular}{ccccc}
\hline Variable & IMAL & IMAN & IMT & LGI \\
\hline Clinically healthy $(\mathrm{n}=33)$ & $0.07 \pm 0.02$ & $0.86 \pm 0.07$ & $2,16 \pm 0.02$ & 0.08 \\
\hline Subclinical mastitis $(\mathrm{n}=37)$ & $0.04 \pm 0.01^{*}$ & $1.44 \pm 0.17 * *$ & $1.91 \pm 0.01 * *$ & 0.04 \\
\hline
\end{tabular}

Notes: the degree of reliability compared with data of the control group: ${ }^{*}-\mathrm{P}<0.05{ }^{* *}-\mathrm{P}<0.01$. 
In the pathogenesis of clinical mastitis also marked characteristic changes in the indicators of immunobiological balance, in particular IMAL, reflecting the intensity of migration of lymphocytes into the inflammation zone. It was found that this index also significantly decreased $(0.05 \pm 0.01)$. This indicates a change in the immunoregulatory function of the local immune defense due to lymphocyte insufficiency (table 2). Changes in the cytological composition also affected the LGI. When purulentcatarrhal mastitis, this indicator is significantly different from the control value of patients with subclinical mastitis of cows.

This phenomenon clearly demonstrates the importance of neutrophil granulocytes in the area of pathological process (fig. 1). Our further researches have proved that the prolonged persistence of neutrophils in the parenchyma of the mammary gland causes serious destructive processes.

DIMAL aIMAN QLGI aNeutrophils, \%

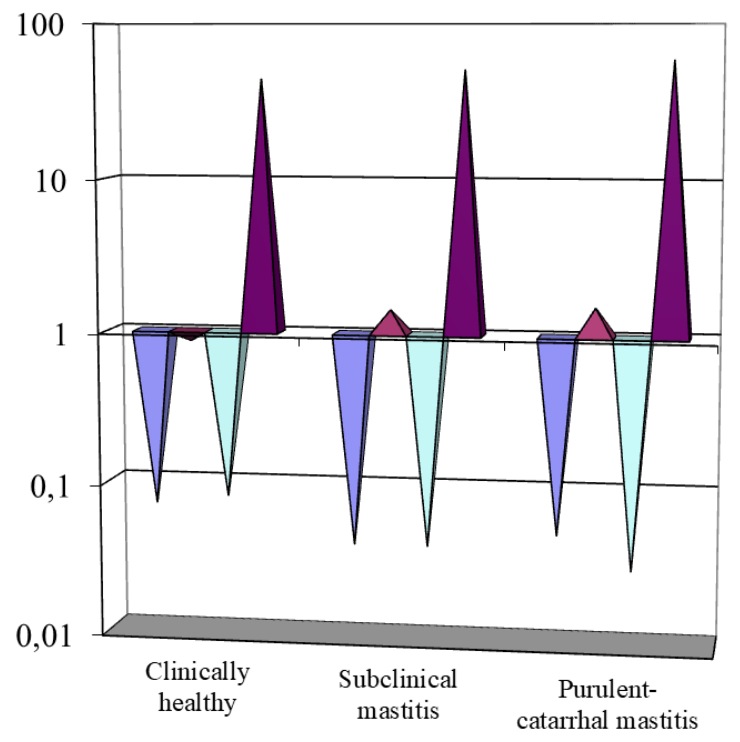

Fig. 1. Changes in the cytological composition of immunocompetent cells of secretion udder in subclinical and purulent catarrhal mastitis $(\mathrm{M} \pm \mathrm{m})$

Consequently, when considering the pathogenesis, along with the quantitative composition, it is necessary to take into account the functional state of the cells, as well as their survival (state of apoptosis), since excessive destruction of phagocytic cells also plays a role in the development of purulent - catarrhal inflammation in the mammary gland.

The cause of mastitis is the pathogenic effect of mechanical, physical, chemical and biological factors on the animal's organism. In this case, in most cases, the etiology of mastitis is multifactorial and the disease always arises on the background of a decrease in immunobiological protection, both at the local and system level, and is accompanied by changes in immune reactivity (Hamilton et al., 2006; Wu et al., 2015). However, the microbial factor is of paramount importance in the application of the pathogenetic mechanisms of this pathology, and therefore knowledge and determination of the biological balance between microorganisms and microorganisms is a significant moment in improving the methods of diagnosis, prevention and treatment of cows (Yablonskyi and Zhelavskyi, 2008; Pang et al., 2017).

Among somatic cells, the highest percentages in these periods belong to neutrophilic granulocytes. The number of polymorphonuclear neutrophils in the secretion of the mammary gland is increasing during the period of secretion of colostrum and at the launch (up to 40\%). Especially the population of neutrophils increases with the development of a mastitis (Green et al., 2007; Blum et al., 2015).

The multifaceted role in the formation of local immunity is performed by the macrophages of the secretion of the mammary gland. However, in functional terms, this cell population is less active than the microphages of the secretion. Neutrophil granulocytes play an important role in the cellular defense of the mammary gland. Under physiological conditions, a significant number of neutrophils is subjected to apoptosis - a physiological regulator of immune homeostasis. It has been shown that a significant amount of neutrophils in the secretion of the mammary gland are inactive and subjected to apoptosis. There are numerous reports (Yablonskyi and Zhelavskyi, 2008) on the dynamic changes in the population of neutrophil granulocytes in secretion in different periods of the functioning of the mammary gland. A clear connection was established between the growth of this cell population with the manifestation of inflammation in the mammary gland.

There is a clear correlation between the number of neutrophils and the risk of developing mastitis in cows. Therefore, according to recent data, neutrophilic granulocytes are considered as one of the main inflammatory effects that trigger a cascade of immunobiological reactions. It is also proved correlation of natural resistance with the number of polymorphonuclear cells in milk - as the main indicator of resistance to infection.

Important in the formation of the immune response are receptors and cytokines. Currently, scientists are studying the role of Toll-like receptors (TLRs) - membrane structures that play an important role in the identification of pathogenic microorganisms (Thompson-Crispi et al., 2014).

We have established cytological methods that subclinical mastitis of cows was accompanied by a sharp increase in the total number of somatic cells. In the secretion of the mammary gland increase the percentage of neutrophil granulocytes, monocytes and histiocytes against the background of an increase in the index of migration activity of neutrophils and a shift in the balance of the lymphocytic granulocytic index. This convincingly proves that subclinical inflammatory mastitis manifests itself by the active migration of phagocytic cells into the pathological process area and the growth of the particle in it phagocytic cells - the first effector unit in the antimicrobial defense system (Yablonskyi and Zhelavskyi, 2007; 2008; 2009; Ruegg et al., 2017).

Manifestation of clinical signs of purulent-catarrhal inflammation of the mammary gland of cows was 
accompanied by a significant increase $(\mathrm{P}<0.01)$ of the total number of somatic cells to $8448.52 \pm 180.98 \mathrm{cell} / \mathrm{ml}$ $\mathrm{x} 1000$. In this case, an increase in neutrophil migration in the pathology zone. This occurred on the background of a decrease in the proportion of monocytes and histiocytes and deeper shifts in cytological indices, was noted.

This phenomenon can be explained by the complete deployment of immunological reactions (Zhelavskyi, 2009; Zhelavskyi, 2010; Ceniti et al., 2017; Cao et al., 2018). This during which there are deficient changes in the parameters of cellular protection associated with disturbed disproportionate balance of cells and their inability to transform (a decrease in the number of histiocytes).

\section{Conclusion}

1. Subclinical mastitis of cows is accompanied by a sharp increase in the total number of somatic cells in the secretion of the mammary gland. This is due to the activity of neutrophil granulocytes, monocytes of histiocytes, which are on the background of an increase in the index of migration activity and a shift in the balance of immunocompetent cells.

2. With purulent-catarrhal mastitis of cows there is a significant increase $(\mathrm{P}<0.01)$ in the somatic cells count (up to $8448.52 \pm 180.98 \mathrm{cell} / \mathrm{ml} \mathrm{x} \mathrm{1000).} \mathrm{Also,} \mathrm{the} \mathrm{migra-}$ tion activity of neutrophils and histiocytes in the pathologic process zone is increasing. And there are also more profound shifts in the balance of immune cells.

3. Our experimental data convincingly confirm that in subclinical and purulent-catarrhal mastitis in cows there are significant changes in the system of local immune defense of the mammary gland. It has an important diagnostic value, and also needs immunocorrection in the treatment process.

Prospects for further research. The results of the research will be used in the future to study the system of congenital immune mammary gland, as well as for the development of immunocorrection therapy for the treatment of cows with mastitis.

\section{References}

Abebe, R., Hatiya, H., Abera, M., Megersa, B., \& Asmare, K. (2016). Bovine mastitis: prevalence, risk factors and isolation of Staphylococcus aureus in dairy herds at Hawassa milk shed, South Ethiopia. BMC Veterinary Research, 12, 270 doi: 10.1186/s12917-016-0905-3.

Al-Farha, A.A.-B., Hemmatzadeh, F., Khazandi, M., Hoare, A., \& Petrovski, K. (2017). Evaluation of effects of Mycoplasma mastitis on milk composition in dairy cattle from South Australia. BMC Veterinary Research, 13, 351. doi: 10.1186/s12917-017-1274-2.

Blum, S.E., Heller, E.D., Sela, S., Elad, D., Edery, N., \& Leitner, G. (2015). Genomic and Phenomic Study of Mammary Pathogenic Escherichia coli. PLoS ONE, 10(9), e0136387. doi: 10.1371/journal.pone.0136387.
Call, D.R., Davis, M.A., \& Sawant, A.A. (2008) Antimicrobial resistance in beef and dairy cattle production. Anim Health Res Rev. Dec; 9(2), 159167. doi: $10.1017 / \mathrm{S} 1466252308001515$.

Cao, Y., Su, B., Chinnaraj, S., Jana, S., Bowen, L., Charlton, S., \& Chen, J. (2018). Nanostructured titanium surfaces exhibit recalcitrance towards Staphylococcus epidermidis biofilm formation. Scientific Reports, 8, 1071. doi: 10.1038/s41598-01819484-x.

Ceniti, C., Britti, D., Santoro, A. M. L., Musarella, R., Ciambrone, L., Casalinuovo, F., \& Costanzo, N. (2017). Phenotypic Antimicrobial Resistance Profile of Isolates Causing Clinical Mastitis in Dairy Animals. Italian Journal of Food Safety, 6(2), 6612. doi: 10.4081/ijfs.2017.6612.

Delfani, S., Bahmani, M., MohammadrezaeiKhorramabadi, R., \& Rafieian-Kopaei, M. (2017). Phytotherapy in Streptococcus agalactiae: An Overview of the Medicinal Plants Effective against Streptococcus agalactiae. Journal of Clinical and Diagnostic Research: JCDR, 11(6), DE01-DE02. doi: 10.7860/JCDR/2017/25530.9988.

Green, M.J., Bradley, A.J., Medley, G.F., \& Browne, W.J. (2007). Cow, Farm, and Management Factors During the Dry Period that Determine the Rate of Clinical Mastitis After Calving. Journal of Dairy Science, 90(8), 3764-3776. doi: 10.3168/jds.2007-0107.

Hamilton, C., Emanuelson, U., Forslund, K., Hansson, I., \& Ekman, T. (2006). Mastitis and related management factors in certified organic dairy herds in Sweden. Acta Veterinaria Scandinavica, 48(1), 11. doi: 10.1186/1751-0147-48-11.

Kempf, F., Slugocki, C., Blum, S. E., Leitner, G., \& Germon, P. (2016). Genomic Comparative Study of Bovine Mastitis Escherichia coli. PLoS ONE, 11(1), e0147954. doi: 10.1371/journal.pone.0147954.

Kurjogi, M. M., \& Kaliwal, B. B. (2014). Epidemiology of Bovine Mastitis in Cows of Dharwad District. International Scholarly Research Notices, 2014, 968076. doi: 10.1155/2014/968076.

Lombardini, M., Meriggi, A., \& Fozzi, A. (2017). Factors influencing wild boar damage to agricultural crops in Sardinia (Italy). Current Zoology, 63(5), 507-514. doi: 10.1093/cz/zow099.

Ndhlovu, D.N., \& Masika, P.J. (2017). In vitro efficacy of extracts from plants used by small-holder farmers in the treatment of dermatophilosis in cattle. African Journal of Traditional, Complementary, and Alternative Medicines, 14(2), 263-272. doi: 10.21010/ajtcam.v14i2.28.

Pang, M., Sun, L., He, T., Bao, H., Zhang, L., Zhou, Y., \& Wang, R. (2017). Molecular and virulence characterization of highly prevalent Streptococcus agalactiae circulated in bovine dairy herds. Veterinary Research, 48, 65. doi: 10.1186/s13567-017-0461-2.

Patent 58403 Ukraina MPK7G 01 N 33/487. Sposib diahnostyky subklinichnoho mastytu koriv / Yablonskyi V.A., Zhelavskyi M.M., Zhuk Yu.V.; zaiavnyk ta vlasnyk Natsionalnyi universytet bioresursiv i 
pryrodokorystuvannia Ukrainy. № u 2010 11656; zaiavl. 28.09.2010; opubl. 11.04.2011, Biul. № 7 (in Ukranian).

Ruegg, P.L. (2017). A 100-Year Review: Mastitis detection, management, and prevention. J Dairy Sci. Dec, 100(12), 10381-10397. doi: 10.3168/jds.201713023.

Sato, T., Usui, M., Konishi, N., Kai, A., Matsui, H., Hanaki, H., \& Tamura, Y. (2017). Closely related methicillin-resistant Staphylococcus aureus isolates from retail meat, cows with mastitis, and humans in Japan. PLoS ONE, 12(10), e0187319. doi: 10.1371/journal.pone.0187319.

Singh, A.V., Vyas, V., Patil, R., Sharma, V., Scopelliti, P.E., Bongiorno, G., \& Milani, P. (2011). Quantitative Characterization of the Influence of the Nanoscale Morphology of Nanostructured Surfaces on Bacterial Adhesion and Biofilm Formation. PLoS ONE, 6(9), e25029. doi: 10.1371/journal.pone.0025029.

Thompson-Crispi, K., Atalla, H., Miglior, F., \& Mallard, B.A. (2014). Bovine Mastitis: Frontiers in Immunogenetics. Frontiers in Immunology, 5, 493. doi: 10.3389/fimmu.2014.00493.

Wang, X., Zhong, J., Gao, Y., Ju, Z., \& Huang, J. (2014). A SNP in intron 8 of $C D 46$ causes a novel transcript associated with mastitis in Holsteins. BMC Genomics, 15(1), 630. doi: 10.1186/1471-2164-15-630.

Wu, J., Li, L., Sun, Y., Huang, S., Tang, J., Yu, P., \& Wang, G. (2015). Altered Molecular Expression of the TLR4/NF- $\kappa B$ Signaling Pathway in Mammary Tissue of Chinese Holstein Cattle with Mastitis. PLoS ONE, 10(2), e0118458. doi: 10.1371/journal.pone.0118458.

Yablonskyi, V.A. \& Zhelavskyi, M.M. (2010). Osoblyvosti projavu klitynnogo imunnogo zahystu organizmu koriv $\mathrm{v}$ rizni periody laktacii. Naukovi dopovidi Nacional'nogo universitetu bioresursiv i pryrodokorystuvannja Ukrainy, 2(20). http://nd.nubip.edu.ua/2010-4/10yvalsm.pdf

(in Ukranian).

Yablonskyi, V.A. \& Zhelavskyi, M.M. (2014). Stan apoptozu imunokompetentnyh klityn sekretu molochnoi zalozy koriv u rizni periody laktacii. Naukovo-tehnichnyi bjuleten' naukovo-doslidnogo centru biobezpeky ta ekologichnogo kontrolju resursiv APK, 2, 3 (in Ukranian).

Yablonskyi, V.A., \& Zhelavskyi, M.M. (2007). Biometrichnyi analiz autoimunnyh reakcij $\mathrm{V}$ organizmi koriv. Veterynarna medycyna Ukrainy, 5, 37-38 (in Ukranian).

Yablonskyi, V.A., \& Zhelavskyi, M.M. (2008). Apoptoz imunokompetentnyh klityn krovi koriv $\mathrm{u}$ period laktacii. Naukovyi visnyk Nacional'nogo agrarnogo universitetu. 126, 233-236 (in Ukranian).

Yablonskyi, V.A., \& Zhelavskyi, M.M. (2008). Doslidzhennja citohimichnoi reaktyvnosti nejtrofiliv krovi koriv $\mathrm{V}$ period laktacii. Naukovi dopovidi Nacional'nogo agrarnogo universitetu, 2(10). http://nd.nubip.edu.ua/2008-2/08yvatol.pdf

(in Ukranian).
Yablonskyi, V.A., \& Zhelavskyi, M.M. (2009). Zminy protymikrobnoi reaktyvnosti fagocytiv sekretu molochnoi zalozy koriv pry subklinichnomu mastyti. Naukovyi visnyk Nacional'nogo universitetu bioresursiv i pryrodokorystuvannja Ukrainy. Serija "Veterynarna medycyna, jakist' i bezpeka produkcii tvarynnyctva", 136, 184-185 (in Ukranian).

Yablonskyi, V.A., Bodnar, O.O. \& Zhelavskyi, M.M. (2001). Shhodo metodyky imunologichnyh obstezhen' tvaryn. Veterynarna medycyna Ukrainy, 6, 46 (in Ukranian).

Zhelavskyi, M. M. (2004). Nespecyfichna reaktyvnist' organizmu koriv pry mastyti. Naukovyi visnyk L'vivs'koi nacional'noi akademii veterinarnoi medycyny im. S.Z. Gzhyc'kogo, 6, 2(1), 31-35 (in Ukranian).

Zhelavskyi, M.M. (2005). Biometrichnyi analiz pokaznykiv nespecyfichnogo imunnogo zahystu koriv $\mathrm{v}$ rizni periody funkcional'nogo stanu molochnoi zalozy. Naukovo-tehnichnyi bjuleten' instytutu biologii tvaryn i Derzhavnogo naukovo-doslidnogo kontrol'nogo instytutu veterynarnyh preparativ ta kormovyh dobavok, 6(2), 70-73 (in Ukranian).

Zhelavskyi, M.M. (2006). Doslidzhennja metabolichnoi aktyvnosti nejtrofiliv molozyva koriv v NST-testi. Naukovyi visnyk L'vivs'koi nacional'noi akademii veterinarnoi medycyny im. S.Z. Gzhyc'kogo, 8, 3(30), 40-42 (in Ukranian).

Zhelavskyi, M.M. (2007). Osoblivosti projavu cytohimichnoi reaktyvnosti kolostral'nyh nejtrofiliv koriv. Zbirnyk naukovyh prac' Lugans'kogo nacional'nogo agrarnogo universitetu. Serija "Veterynarni nauky", 78(101), 203-205 (in Ukranian).

Zhelavskyi, M.M. (2008). Funkcional'na aktyvnist' ta stan apoptozu fagocytiv krovi koriv $\mathrm{v}$ period laktacii. Naukovyi visnyk L'vivs'kogo nacional'nogo universytetu veterinarnoi medycyny ta biotehnologij im. S.Z. Gzhyc'kogo, 10, 2(37), 72-75 (in Ukranian).

Zhelavskyi, M.M. (2009). Znachennja cirkuljujuchyh imunnyh kompleksiv $\mathrm{v}$ patogenezi subklinichnogo mastytu koriv. Naukovyi visnyk L'vivs'kogo nacional'nogo universytetu veterinarnoi medycyny ta biotehnologij im. S.Z. Gzhyc'kogo, 11, 3(42), 46-49 (in Ukranian).

Zhelavskyi, M.M. (2010). Zmini fagocitarnogo zahistu organizmu koriv pri subklinichnomu mastiti. Naukovyi visnyk L'vivs'kogo nacional'nogo universytetu veterinarnoi medycyny ta biotehnologij im. S.Z. Gzhyc'kogo. Serija "Veterinarni nauky", 12, 2(44), 93-96 (in Ukranian).

Zhelavskyi, M.M. (2011). Zmina Oksygennezalezhnogo protymikrobnogo potencialu fagocytiv sekretu molochnoi zalozy koriv za subklinichnogo mastytu. Naukovyi visnyk L'vivs'kogo nacional'nogo universytetu veterinarnoi medycyny ta biotehnologij im. S. Z. Gzhyc'kogo. Serija "Veterinarni nauky", 13, 4(50), 124-127 (in Ukranian).

Zhelavskyi, M.M. (2017). Ontogenetic features of the formation of local immune protection of the mammary gland of cows (literature review and original 
research). Scientific Messenger of Lviv National University of Veterinary Medicine and Biotechnologies named after S.Z. Gzhytskyj, 19(79), 3-8. doi: 10.15421/nvlvet7801.

Zhelavskyi, M.M., \& Shunin, I.M. (2017). The status of extracellular antimicrobial potential of phagocytes genitals of cats. Scientific Messenger of Lviv National University of Veterinary Medicine and Biotechnologies named after S.Z. Gzhytskyj, 19(73), 71-74. doi: 10.15421/nvlvet7315.

Zhelavskyi, N.N. (2012). Izmenenie funkcional'nogo sostojanija kletochnogo immuniteta i apoptoz immunokompetentnyh kletok pri mastite korov: materialy Mezhdunarodnoj nauchno-prakticheskoj konferencii, posvjashhennoj 85-letiju so dnja rozhdenija professora Cheremisinova G.A. i 50-letiju sozdanija Voronezhskoj shkoly veterinarnyh akusherov (18.10-19.10, Voronezh, 2012 goda), 201205 (in Russian).

Zhelavskyi, N.N. (2015). Funkcional'noe sostojanie kletochnyh faktorov lokal'nogo immuniteta molochnoj zhelezy korov $\mathrm{v}$ razlichnye periody laktacii.
Aktual'nye problemy intensivnogo razvitija zhivotnovodstva: sbornik nauchnyh trudov UO "Belorusskaja gosudarstvennaja sel'skohozjajstvennaja akademija". 18(2), 187-197 (in Russian).

Zhelavskyi, N.N. (2017). Izmenenie lokal'noj immunnoj zashhity molochnoj zhelezy korov pri mastite. Uchenye zapiski uchrezhdenija obrazovanija "Vitebskaja ordena "Znak pocheta" gosudarstvennaja akademija veterinarnoj mediciny”. 53(2), 53-56. http://repo.vsavm.by/handle/123456789/2023 (in Russian).

Zhelavskyi, N.N., \& Yablonskyi, V.A. (2009). Izmenenie funkcional'nogo sostojanija kletochnogo zvena immunobiologicheskoj zashhity organizma korov pri subklinicheskom mastite. Uchenye zapiski: Nauchnoprakticheskij zhurnal uchrezhdenija obrazovanija "Vitebskaja ordena "Znak Pocheta" gosudarstvennaja akademija veterinarnoj mediciny". Vitebsk: Vitebskaja ordena "Znak Pocheta" gosudarstvennaja akademija veterinarnoj mediciny, 45(1), 244 -246 (in Russian). 